\title{
The Effects of Knowledge Creation Process upon the Organizational Performance: A Study of Thai Banking Industry
}

\author{
Cheewanan Arijitsatien and Vichita Vathanophas Ractham
}

\begin{abstract}
As knowledge-based economy emerged, knowledge management (KM) turns to be a principle for organizations to maximize to the value of knowledge. Among KM domains, knowledge creation is the most concerned aspect when it comes to innovation, creativity, performance, and learning. Reviewing on academic literature, the application of SECI model, a well-known knowledge creation theory, is hardly seen in Southeast Asian countries especially in banking industry. The objective of this study is to investigate the effects of knowledge creation upon the organizational performance. The research scope is banking industry in Thailand, focusing on commercial banks. The goal of research was achieved by developing statistical testing using multiple regression. Findings indicate that knowledge creating process positively affect to organizational performance. However, based on Holistic scorecard framework, not all modes of SECI process significantly affect to each perspective of organizational performance. Knowledge creation process is also influenced by collective culture and the nature of banking industry which makes each SECI process affects differently to organizational performance.
\end{abstract}

Index Terms-Knowledge creation process, SECI model, knowledge management, organizational performance.

\section{INTRODUCTION}

Since the world economy has moved to the knowledge based and global economy, Knowledge management (KM) becomes the important principle in organizations to maximize the value of knowledge and capture them from knowledge workers. There are two main points why an organization needs KM. First, knowledge is like other resources which require management to support allocation and development. Second, management mechanisms are needed to change knowledge into business outcomes [1]. KM has become the topic in banking industry since 1996 when World Bank initiated KM concept [2]. It is truly important in banking industry because banking operations required the higher complexity of knowledge than in most industries [3]. Even though KM is one of the key success factors in banking business, it seems to have a few interesting of KM within banks in Southeast Asian countries. Therefore, there is still have room for further studies of $\mathrm{KM}$ in these countries.

Considering among KM domains, "Knowledge Creation" is

Manuscript received July 12, 2017; revised September 15, 2017.

Cheewanan Arijitsatien and Vichita Vathanophas Ractham are with the College of Management, Mahidol University, Thailand (e-mail: cheewanan.a@gmail.com, vichita.rac@mahidol.ac.th). the most concerned aspect when it comes to innovation, creativity, performance, and learning. The quicker the creation and consolidation of knowledge in business process, the higher capability to innovate of an organization [4]. Knowledge Creation is mainly about knowledge generation and application which leads to the company's new capabilities while innovation is concerned with turning the new capabilities into value products and services [5]. In term of creativity, the larger of knowledge based in organization, the higher level of advanced learning and finally leads to higher organizational creativity [6]. As the view of organizational performance, knowledge creation process has a significant connection with organizational learning which is playing the important role in improving organizational performance [7].

With the lack of KM research in Southeast Asian countries particularly in banking industry and the importance of knowledge creation to the organizational performance, a study of knowledge creation within banking context should be conducted. The aim of this study is to explore the effects of knowledge creation process (KCP) towards banking performance and investigate on the variables of KCP that affect the organizational performance in Thai bank context.

\section{LITERATURE REVIEW}

\section{A. Tacit and Explicit Knowledge}

Knowledge can be classified into two main groups; tacit and explicit knowledge. Tacit knowledge is knowledge that is difficult to describe into words. This kind of knowledge involves with action, procedures, values, experience, and emotion. It is processed in human mind and difficult to share to others. Explicit knowledge is the process when individuals extract information and process from memory which can be represented into words and/or visuals. It is easy to transfer between individuals. Explicit knowledge is stored in form of tangible assets such as documents, data, and manuals etc. [8], [9].

\section{B. Knowledge Creation: SECI Model}

A distinction between two types of knowledge is one dimension of KCP. Another dimension is the ontological dimension or the social interaction level. Knowledge is created by individuals at fundamental level. In organization, knowledge is generated from a group of individuals then it is summarized and connected to a knowledge network in 
organization. First, informal interaction is established as a small community then it becomes more and more formal interaction when spread over organization hierarchy or inter-organizations [10], [11]. With two dimensions of KCP, it becomes the spiral shape model which identifies the conversion between tacit and explicit knowledge. The form of knowledge conversion contains four different patterns. From tacit to tacit knowledge (Socialization), From tacit to explicit knowledge (Externalization), From explicit to explicit knowledge (Combination), and From explicit to tacit knowledge (Internalization). The four conversion modes called "the SECI model". The movement from each conversion mode to one another is in a spiral form. The interaction process is amplified and become in larger scale as it moves up through the ontological levels. Fig. 1 illustrates the four modes of knowledge conversion and the spiral movement in each stage [8].

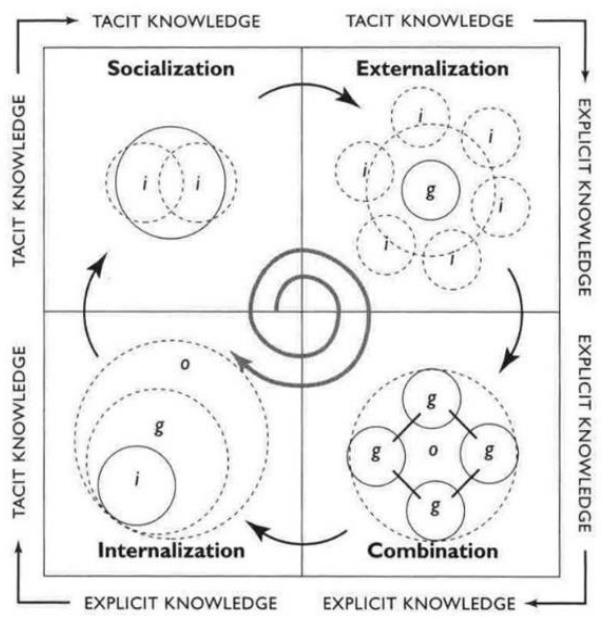

individual g: group o: organization

Fig. 1. SECI process.

1)Socialization $(S)$

Socialization describes the process that tacit knowledge turn into new tacit knowledge. The new tacit knowledge is created through the sharing experience [8].

\section{2)Externalization $(E)$}

Externalization is a conversion process of tacit knowledge into explicit knowledge. Externalization is the key of KCP as it turns tacit knowledge into new explicit knowledge. When tacit is transformed into explicit, knowledge becomes crystalized and can be shared by others, then it becomes the foundation of new knowledge [8].

\section{3)Combination (C)}

Combination refers to the process of combining different explicit knowledge and converting into more complex and structured sets of explicit knowledge [8]. Combination stage involves three processes [12]. Capturing and collecting new explicit knowledge from inside and outside groups. Second, disseminate explicit knowledge among the groups using such media as meetings, telephone conversions or large-scale databases and computerized network. Third, editing or processing knowledge into more useful forms e.g. reports, plans.

\section{4)Internalization (I)}

Internalization explains a process that shapes explicit knowledge into tacit knowledge. The self-transcendence process is required when individual accesses explicit knowledge created and shared in the group level, then converts into tacit knowledge. It is closely related to "Learning by doing" [8].

\section{Organizational Performance: Holistic Scorecard}

Performance is the key to indicate firm's position and its survival to compete in the business world [13]. It has been recognized that better organizational performance is from organizations which are managed by using the formalized, balanced, and integrated performance measures [14]. In this research, "Holistic scorecard (HSC)" framework is adopted to measure organizational performance. HSC framework has six dimensions which are financial, customer, business process, intellectual capital, employee, and social perspective [15].

\section{1)Financial perspective}

Financial perspective mostly uses data from financial statement. Information from financial measures depicts organization's investment and helps evaluate the profitability.

\section{2)Customer perspective}

Organizations should have the ability to satisfy existing customers and obtain new customers to gain higher performance. This leads to customer royalty which is the key to maintain customers in organization. Customer perspective is divided into three parts; Customer satisfaction, Customer acquisition, and Return on relationships.

\section{3)Business process perspective}

Business process concerns about a set of processes that create values to customers by using employees and other strategic plans. In other words, customer performance is the evidence of how good of organization's processes, decisions, and actions. HSC framework covers three aspects; Regular business process, Risk management process, and KM process.

\section{4)Intellectual capital perspective}

Intellectual capital is defined as an intangible asset in which its essential part is an idea or knowledge. It can be separated into two aspects; Human capital and Organizational capital. Human capital is associated with employee's ability, whereas organizational capital is related to the cerebral assets, intellectual property, and knowledge asset embedded in processes and culture of organization.

\section{5)Employee perspective}

Employees are the significant stakeholder in organization. Aside from skills and knowledge which are grouped as a part of intellectual capital, employee perspective also considers on four elements; recruitment, selection and retention, training and education, corporate culture, and employee satisfaction.

\section{6)Social perspective}

Social perspective represents quality and value of relationships of organization to society. It points out to the ability in promoting ethical conduct in every organization activities. This aspect is categorized into Political image and 
Social image. Political image refers to the compatibility and consideration with both local and international government whereas Social image regards corporate citizenship, goodwill, contribution to society such as welfare activities, education and career consulting, employment opportunity for disabilities etc.

\section{Knowledge Creation and Organizational Performance}

In the new economy, performance does not reflect from traditional financial performance but non-financial performance seems to have more significant [16]. The success of firm mostly depends on innovation which can be implied of knowledge creation [17]. There are numerous researches regarding $\mathrm{KCP}$ and organizational performance to understand how it relates to organizational performance and what influential factors to stimulate knowledge creation are in different contexts. It is found that $\mathrm{KCP}$ has significant and positive relationship to different perspectives such as efficiency, innovation, creativity, or learning and some researches find different impact of each knowledge conversion mode to performance perspectives as shown in Table I.

TABLE I: RESEARCHES ON KCP IN DIFFERENT PERFORMANCE PERSPECTIVES

\begin{tabular}{|c|c|c|c|}
\hline $\begin{array}{l}\text { Performance } \\
\text { perspective }\end{array}$ & Key findings & Effect of SECI process & Reference \\
\hline $\begin{array}{l}\text { Novelty of product } \\
\text { idea }\end{array}$ & $\begin{array}{l}\text { KCP has significant relationship to novelty of product idea but not all four modes } \\
\text { positively relate to the novelty of product idea. }\end{array}$ & $\begin{array}{l}\text { S - Positive } \\
\text { E - Negative } \\
\text { C - Negative } \\
\text { I - Positive }\end{array}$ & [18] \\
\hline $\begin{array}{l}\text { New product } \\
\text { performance }\end{array}$ & $\begin{array}{l}\mathrm{KCP} \text { positively relates to new product performance and creativity is a mediator on this } \\
\text { relationship. }\end{array}$ & $\begin{array}{l}\text { S - Insignificant Negative } \\
\text { E - Insignificant Negative } \\
\text { C - Positive } \\
\text { I - Positive }\end{array}$ & [19] \\
\hline \multirow{2}{*}{ Human capital } & KCP significantly influences on human capital. & \multirow{2}{*}{$\begin{array}{l}\text { No investigation on each } \\
\text { SECI process }\end{array}$} & [3] \\
\hline & $\mathrm{KCP}$ is positively affect to human capital and help firm improves intellectual capital. & & [20] \\
\hline \multirow{2}{*}{$\begin{array}{l}\text { Organizational } \\
\text { learning }\end{array}$} & $\begin{array}{l}\text { KCP plays a mediating role through which organizational learning improves } \\
\text { organizational performance. }\end{array}$ & \multirow{2}{*}{$\begin{array}{l}\text { S - Positive } \\
\text { E - Positive } \\
\text { C - Positive } \\
\text { I - Positive }\end{array}$} & [7] \\
\hline & $\mathrm{KCP}$ has a significant and positive effect on organizational learning. & & {$[21]$} \\
\hline \multirow{2}{*}{ Innovation } & $\begin{array}{l}\mathrm{KCP} \text { whether as a whole or separate process is positively influence innovation } \\
\text { process. }\end{array}$ & $\begin{array}{l}\text { S - Positive } \\
\text { E - Positive } \\
\text { C - Positive } \\
\text { I - Positive }\end{array}$ & [2] \\
\hline & $\begin{array}{l}\mathrm{KCP} \text { is a critical driver for innovation performance in firms and acts as a partial } \\
\text { mediator in the link between learning organizational practices and innovation } \\
\text { performance. }\end{array}$ & $\begin{array}{l}\text { No investigation on each } \\
\text { SECI process }\end{array}$ & [22] \\
\hline \multirow{3}{*}{$\begin{array}{l}\text { Organizational } \\
\text { performance }\end{array}$} & $\begin{array}{l}\mathrm{KCP} \text { is strongly positive to organizational improvement and is estimated to be } 40 \% \text { of } \\
\text { organizational performance. }\end{array}$ & $\begin{array}{l}\text { S - Positive } \\
\text { E - Positive } \\
\text { C - Positive } \\
\text { I - Positive }\end{array}$ & [23] \\
\hline & $\begin{array}{l}\mathrm{KCP} \text { has direct affect to organizational performance and mediates the relationship of } \\
\text { entrepreneurial orientation and organizational performance. }\end{array}$ & \multirow[b]{2}{*}{$\begin{array}{l}\text { No investigation on each } \\
\text { SECI process }\end{array}$} & [24] \\
\hline & $\begin{array}{l}\text { KCP has positive impact to organizational performance but its mediating effect in the } \\
\text { relationship of entrepreneurial orientation and organizational performance is } \\
\text { insignificant. }\end{array}$ & & [25] \\
\hline
\end{tabular}

\section{RESEARCH HYPOTHESES}

As discussed earlier, KCP refers to the four modes of knowledge conversion; socialization, externalization, combination, and internalization. These four knowledge conversion modes combine into continuous processes. KCP expands from individuals to group and organization level. As a result, SECI model creates knowledge memory to organization. It adds value to organizations, helps firms to integrate emerging knowledge into strategic development [11], expands organizational learning, utilizes human capital, and enhances processes. Hence, it is believed that organizations with better KCP will lead to better performance. Organizational performance is based on HSC. Thus, it becomes the hypotheses for this study as the following;

$\mathrm{H} 1$ : KCP positively relates to organizational performance

$\mathrm{H} 2$ : KCP positively relates to financial performance

$\mathrm{H} 3$ : KCP positively relates to customer performance
$\mathrm{H} 4$ : KCP positively relates to business process performance H5: KCP positively relates to intellectual capital performance

H6: KCP positively relates to employee performance

$\mathrm{H} 7$ : KCP positively relates to social performance

\section{RESEARCH METHODOLOGY}

\section{A. Sample and Data Collection}

This study uses questionnaire to collect respondent's perception regard to SECI activities and organizational performance. The Likert-scale is used, ranging from 1 to 5 which are strongly disagree (1) - disagree (2) - neutral (3) agree (4) - strongly agree (5). The study focuses on banking industry in Thailand. The primary priority is 14 Thai commercial banks as they have the share of $47.9 \%$ of total asset of financial institutions which is the largest share in 
Thailand's financial institutions [26]. Total sample size in this study is 400 banking employees.

\section{B. Measurement of Variables}

SECI process contains 19 items adapted from the study of [2], [5], [18], [23], [27], and [28]. Organizational performance is measured by using 36 items which are adjusted from the work of [13], [29]-[35].

\section{Quality of Measurement}

\section{1)Reliability}

Cronbach's alpha is used to estimate the reliability of variables. The acceptance values of alpha recommended in many researches vary from 0.70 to 0.95 [36]. The alpha values of all variables exceed 0.7 which is a proof of high reliability in the questionnaire.

\section{2) Validity}

There are three kinds of validity that are using frequently in quantitative researches; content, construct, and criterion [37]. In this study, the selection of variables is based on comprehensive review of the literatures. Thus, adequate variables are captured. It can be concluded that the questionnaire has a reasonable degree of content validity.

Factor analysis by using principle component analysis method is used to assess construct validity. The variables are extracted into 4 factors; socialization, externalization, combination, and internalization. The factor loading of all items are higher than the 0.5 . This is an evidence that the questionnaire items are well represented for each SECI variable, revealing the acceptance level of construct validity.

Criterion validity can be assessed by examining the multiple correlation coefficient (R), the multiple correlation coefficients of all hypotheses are greater than 0.5 which indicates the high degree of criterion validity.

\section{Data Analytical Method}

This study uses SPSS statistics software to explore and analyze data. Multiple regression indicates the importance of each independent variables toward the dependent variables. It is used to test all hypotheses to understand the relationship of SECI process and the organizational performance.

\section{DATA ANALYSIS}

\section{A. Hypotheses Testing}

Factor analysis is used to obtain factors. The factor scores are used as the input of independent variables. The organizational performance is obtained from average perception scores of the questionnaire items and it is used as the dependent variables in the statistical analysis. Before running regression, it is important to understand the assumptions of regression to justify the use of it for inference or prediction. There are four assumptions that researchers should aware; normality, linearity, reliability, and homoscedasticity. All assumptions should not be violated to prove the accuracy of regression model [38]. Multiple regression with stepwise method is selected to remove the insignificant variable for dependent variable from equation.

\section{1)Testing hypothesis 1}

The overall model is significant with $\mathrm{P}$ value $=0.000$. The calculated F is 510.638 whereas the critical F is 2.394 (df: 4, 395 and $\mathrm{P}<0.05$ ). Hence, $\mathrm{H} 1$ is accepted. The result states that KCP positively relates to organizational performance in Thai banking industry. The largest effect to organizational performance is socialization, followed by externalization, internalization and combination. The regression equation can be defined as equation below.

Organizational Performance' $=3.988+0.199(\mathrm{~S})+0.188(\mathrm{E})$ $+0.155(\mathrm{I})+0.091(\mathrm{C})$

\section{2)Testing hypothesis 2}

The overall model is significant. The calculated $\mathrm{F}$ value is 118.786 and the critical $F$ is 2.627 (df: 3, 396 and $P<0.05$ ). Hence, $\mathrm{H} 2$ is accepted that KCP positively relates to financial performance in Thai banking context. Socialization is the most important factor, followed by combination and internalization. Externalization is excluded from the regression which can be interpreted that there is no relationship between externalization and financial performance. The regression equation is expressed as the following:

Financial Performance' $=4.089+0.216(\mathrm{~S})+0.17(\mathrm{C})+$ $0.165(\mathrm{I})$

\section{3)Testing hypothesis 3}

In $\mathrm{H} 3$, the assumption of normally distributed residuals is violated. The result from normality testing indicates that $\mathrm{P}$ value was 0.015 which is less than significance level at $5 \%(\mathrm{P}$ $<0.05$ ), meaning that the residuals are non-normally distributed which leads to the untrustworthy regression model [39]. This can be interpreted that KCP cannot fully explains the variance of customer performance in Thai banking context or there are more important variables which are not included into the model. As such, $\mathrm{H} 3$ is accepted but the accuracy of the regression model is weaken by non-normality of residuals.

\section{4)Testing hypothesis 4}

The overall model is significant and the calculated $F$ value is 412.742 which is greater than the critical $F$ value; 2.394 (df: 4, 395 and $\mathrm{P}<0.05$ ), accordingly, $\mathrm{H} 4$ is accepted. There is a positive relationship of $\mathrm{KCP}$ and business process performance in the context of Thailand's banking industry. Internalization is the most important factor, then externalization, socialization, and combination respectively. The equation for $\mathrm{H} 4$ is stated below.

Business Process Performance' $=3.995+0.196(\mathrm{I})+$ $0.184(\mathrm{E})+0.179(\mathrm{~S})+0.134(\mathrm{C})$

\section{5)Testing hypothesis 5}

The overall model is significant. The calculated $\mathrm{F}$ value is 242.71 which is higher than the critical F; 2.394 (df: 4, 395 and $\mathrm{P}<0.05$ ). Hence, $\mathrm{H} 5$ is accepted. The results confirm that $\mathrm{KCP}$ positively relates to intellectual capital performance within Thai's banks. The strengths of effects from strong to weak are internalization, externalization, socialization, and combination respectively. The regression equation can be expressed as: 
Intellectual Capital Performance' $=3.987+0.2(\mathrm{I})+$ $0.179(\mathrm{E})+0.17(\mathrm{~S})+0.076(\mathrm{C})$

\section{6)Testing hypothesis 6}

The regression model is significant. The calculated $\mathrm{F}$ value is 289.943 which is greater than the critical F; 2.627 (df: 3, 396 and $\mathrm{P}<0.05)$. In consequence, H6 is accepted which states that there is a relationship between $\mathrm{KCP}$ and employee performance. There are 3 variables that positively significant to employee performance. Externalization is the most important factor then followed by socialization and internalization respectively. Combination is excluded which can be interpreted that there is no relationship between combination and employee performance in the context of banking in Thailand. The equation of employee performance is stated below.

Employee Performance' $=3.891+0.248(\mathrm{E})+0.236(\mathrm{~S})+$ $0.16(\mathrm{I})$

\section{7)Testing hypothesis 7}

The regression result is statistically significant. The calculated F is 143.873 and the critical F is 2.627 (df: 3, 396 and $\mathrm{P}<0.05$ ). The regression results confirm that KCP positively relates to social performance in Thai banking context. Socialization, externalization, and combination are found to have positive relationship with social performance whereas internalization had no relationship with social performance because it is excluded from regression model. Beta coefficients show that socialization is the most important factor. The next factor is externalization and the last factor is combination. The regression equation is shown below.

Social Performance' $=4.1+0.247(\mathrm{~S})+0.151(\mathrm{E})+0.116(\mathrm{C})$

\section{Results AND CONCLUSION}

The results reveal that KCP positively affects to the banking performance but not all SECI processes have the significant effect toward each perspective of organizational performance. Surprisingly, SECI process has found to be the unimportant factor for customer performance, revealing that the activities of knowledge creation in Thai banks cannot reflect to customer performance. This can be implied that the spiral movement of SECI process in Thai banks cannot reach beyond boundary of organization.

Socialization is the main process in Thai banking industry as it affects to every perspective of organizational performance (except customer perspective) with the highest magnitude comparing to the other SECI processes. This reveals that employees in Thai banks focus more on tacit knowledge sharing to perform their jobs. Socialization also impacts to the working atmosphere such as trust, openness and good relationships among employees which is a part of employee performance. This aligns with the research that shows trust increased from formal socialization increases trust in business environment [40]. The large effect of socialization can be from collectivist society in Thailand which drives these social activities. Moreover, banking industry is a service industry. Thus, it requires a lot of social interactions in the working process when compared with other industries such as manufacturing industry.

Externalization positively affects to business process, intellectual capital, employee, and social perspectives. However, it does not affect to financial performance. This can be explained by the nature of banking industry which is required to comply with the regulations and acts. Banking employees need to consider organizational norms and expectations along with regulations and acts before expressing their tacit knowledge. It leads to fear of making mistakes attitude and hinders externalization process. Activities of externalization create new explicit knowledge for organization which can be shared to other members in organization. It reduces time and cost for organization as other members can learn from that explicit knowledge. Hence, fear of making mistakes limit externalization and minimize its benefits within Thai banks in financial aspect.

The activities of combination positively affect to financial, business process, intellectual capital, and social performance. However, the effect size of combination towards intellectual capital and social performance are in minor degrees. This can relate to the quality of knowledge in organization. Outdated knowledge hinders the combination process as employees feel unconfident to use that knowledge which is resulted in less new explicit knowledge and therefore, lowers the intellectual capital in Thai banks. Moreover, the small extent of combination toward social performance can be from the perception of activities in social perspective as Thai organizations perceive social activities such as CSR activities as non-related working activities [41]. As a result, combination process is like social activities in socialization rather than combination process which is more related with utilizing knowledge. Additionally, combination is identified to be a non-essential factor for employee performance. This can be from the individual perception in employee perspective such as working atmosphere, pay and benefit satisfaction cannot be fulfilled by the combination activities.

Internalization process positively affects to financial, business process, intellectual, and employee performance. Internalization has the highest effect size on business process and intellectual capital perspectives. This marks the importance of converting explicit into tacit knowledge which drives business activities and increases knowledge assets in Thai banks. This finding is in line with another research, indicating that the more engagement in socialization and internalization, the deeper knowledge that employees gain in the educational context [42]. In the opposite way, internalization does not affect to organizational performance in social perspective. This can be explained by the perception of non-related working activities in social perspective which limits the internalization processes within Thai banks.

\section{IMPLICATIONS}

Implications provided suggestions for Thai banks to maximize the benefits of KCP based on SECI model. The discussion presents the ways to enhance knowledge creation activities and accordingly lead to higher organizational performance based on HSC framework. The implications are 
divided into two parts in term of development and improvement. Development refers to the practices for Thai banks to strengthen knowledge creation activities. Improvement is relevant to the suggestions to fill the gap in knowledge creation activities. For development, the practical contributions of this study are stated as follow:

1. With the importance of internalization in business process and intellectual capital performance, it is recommended to increase internalization activities to boost up performance in both perspectives. On-the-job training is the easiest activity to implement as it can be a part of working processes. Pairing program between employees encourages this activity. The pairing program can be in different dimensions such as between new and existing employees like buddy program or coaching program. On-the-job training motivates face-to-face discussions and increases trust between employees which means that it increases growth in both socialization and internalization processes.

2. In the aspect of employee performance, banks should maximize the benefits of externalization process by using knowledge from expert to set up training programs, recruitment strategy, or career path. Additionally, HR department should know the existing knowledge that organization have and recruit employees whose competence are be able to fulfill knowledge gap in organization.

3. The largest effect of socialization towards financial and social performance indicates its impacts to both perspectives. Hence, increasing socialization activities help banks to achieve better performance in financial and social aspects. Mentoring and apprenticeship allows lower experienced employees to improve their skills from experience sharing with higher experienced employees. Banks should encourage this activity to build up employees' interactions and reduce training cost for new employees which leads to better financial performance. Additionally, banks should support social activities that contribute to society such as an outing program for welfare activity. This activity creates engagements among employees and uplifts social performance in organization.

In the improvement dimension, practical implications are provided in below section.

1. The practice of SECI process can be used to gain insight information from customers to extend the boundary of $\mathrm{KCP}$ with customers. For example, employees at branches can do face-to-face discussion with customers then pass out customers' needs to the relevant teams. The relevant teams gather information from all branches, analyze it and come out with new products/services that serve customers' needs. With technology nowadays allows banks to get close to customers. The relationship and interactions between banks and customers can be established not only in the physical space but also in the virtual space. Customers' information can be obtained from social media and virtual community of practice. In this way, the virtual space enhances and supports SECI activities at the inter-organizational level [43].

2. Banks should create the knowledge sharing environment to facilitate the knowledge expression. Offering rewards or recognitions for employees who have shared useful knowledge is another way to increase employees' motivation. When a lot of tacit knowledge is converted into explicit knowledge, it can be discovered by other members in organization. Thus, time and cost of learning will be reduced and it is reflected to better financial performance. Moreover, this also increases the intellectual capital in banks when knowledge is expanded to organizational level.

3. Regarding the lowest effect of combination toward organizational performance, it indicates the low activities in utilizing organizational knowledge. Therefore, it is recommended to promote the combination activities in Thai banks. To do that, banks need to ensure that the organizational knowledge is up-to-date. Outdated database causes lack of confidence in organizational knowledge and hinder combination processes. The issue of outdated knowledge should be aware as data and information in banking industry is one of the most important keys for competitive advantage. If banks cannot maintain their internal knowledge, then banks cannot survive in the age of big data.

4. Banks should consider welfare activities as a part of business's activities to increase organizational knowledge and gain benefits from those activities. It should be the activities that can turn into business's values. For example, loan offering to eco-friendly product inventors or deposit account with special interest rate for children to encourage saving habit. Contribution to society with business-related objective increases the use of SECI process and brings benefits to both organization and society which finally reflects to better social performance.

\section{LIMITATIONS AND RECOMMENDATIONS FOR FURTHER RESEARCH}

The study is designed to perform analysis with a cross-sectional data. Hence, it is limited to examine the effect of KCP upon organizational performance over a period. In addition, it is limited to collect objective performance because of confidential issue in banking industry.

For further study, there are several additional areas to be recommended. It is suggested to use qualitative method to enhance the quantitative results as qualitative method can obtain in-depth information from participants. Another suggestion is to explore the effect of SECI process toward different aspects in banking industry such as innovation, organizational learning etc. to expand the extent of SECI process in a variety of dimensions in banks. Moreover, it will be useful to explore the link of other KM domains toward organizational performance and the link between knowledge creation and other KM domains. This will increase more understanding not only on knowledge creation but a whole domain of KM upon organizational performance.

\section{REFERENCES}

[1] G. Schiuma, "Managing knowledge for business performance improvement," Journal of Knowledge Management, vol. 6, no. 4, pp. 515-522, 2012

[2] N. F. H. Easa, "Knowledge management and the SECI model: A study of innovation in the Egyptian banking sector," Ph.D. dissertation, Stirling Univ., Stirling, Scotland, 2012. 
[3] K. H. Shih, C. J. Chang, and B. Lin, "Assessing knowledge creation and intellectual capital in banking industry," Journal of Intellectual Capital, vol. 11, no. 1, pp. 74-89, 2010.

[4] V. H. Dos Santos Ferreira and A. Santos, "The impact of knowledge management in innovation performance in the Leiria region," in Proc the European Conference on Intellectual Capital, 2014, Ed. Dagmar Cagáňová and Miloš Čambál, pp. 24-32.

[5] S. Popadiuk and C. W. Choo, "Innovation and knowledge creation: How are these concepts related?" International Journal of Information Management, vol. 26, pp. 302-312, 2006.

[6] A. T. Koh, "Linking learning, knowledge creation, and business creativity: A preliminary assessment of the east Asian quest for creativity," Technological Forecasting and Social Change, vol. 64, pp. 85-100, 2000.

[7] A. M. Ramírez, V. J. G. Morales, and R. M. Rojas, "Knowledge creation, organizational learning and their effects on organizational performance," Engineering Economics, vol. 22, no. 3, pp. 309-318, 2011.

[8] I. Nonaka, R. Toyama, and N. Konno, "SECI, Ba and leadership: A unified model of dynamic knowledge creation," Long Range Planning, vol. 33, pp. 5-34, 2000.

[9] D. Bennet and A. Bennet, "Associative patterning:The unconscious life of an organization," in Building Organizational Memories: Will You Know What You Knew? J. P. Girard, Ed. Hershey: Information Science Reference, 2009, pp. 201-224.

[10] I. Nonaka and H. Takeuchi, The Knowledge-Creating Company, New York: Oxford University Press, 1995.

[11] I. Nonaka, "A dynamic theory of organizational knowledge creation," Organization Science, vol. 5, no. 1, pp. 14-37, 1994.

[12] I. Nonaka and N. Konno, "The concept of "Ba": Building a foundation for knowledge creation," California Management Review, vol. 40, no. 3, pp. 40-54, 1998

[13] Y. Wang, R. Bhanugopan, and P. Lockhart, "Examining the quantitative determinants of organizational performance: Evidence from China," Measuring Business Excellence, vol. 19, no. 2, pp. 23-41, 2015.

[14] U. S. Bititci, K. Mendibil, S. Nudurupati, T. Turner, and P. Garengo, "The interplay between performance measurement, organizational culture and management styles," Measuring Business Excellence, vol. 8 , no. 3, pp. 28-41, 2004.

[15] G. S. Sureshchandar and R. Leisten, "Holistic scorecard: Strategic performance measurement and management in the software industry," Measuring Business Excellence, vol. 9, no. 2, pp. 12-29, 2005.

[16] J. Cumby and J. Conrod, "Non-financial performance measures in the Canadian biotechnology industry," Journal of Intellectual Capital, vol. 2, no. 3, pp. 261-272, 2001

[17] I. J. Walsh, M. Bhatt, and J. M. Bartunek, "Organizational knowledge creation in the Chinese context," Management and Organization Review, vol. 5, no. 2, pp. 261-278, 2009.

[18] A. Schulze and M. Hoegl, "Organizational knowledge creation and the generation of new product ideas: A behavioral approach," Research Policy, vol. 37, pp. 1742-1750, 2008.

[19] J. J. Chang, K. P. Hung, and M. J. J. Lin, "Knowledge creation and new product performance: The role of creativity," $R \& D$ Management, vol. 44 no. 2, pp.107-123, 2014.

[20] G. Mehralian, J. A. Nazari, P. Akhavan, and H. R. Rasekh, "Exploring the relationship between the knowledge creation process and intellectual capital in the pharmaceutical industry," The Learning Organization, vol 21, no. 4, pp. 258-273, 2014.

[21] S. Berraies and M. Chaher, "Knowledge creation process and firms' innovation performance: Mediating effect of organizational learning," International Journal of Human Resource Studies, vol. 4, no. 1, pp. 204-222, 2014

[22] S. H. Laeeque, S. F. Babar, and H. M. Ahmad, "The integrative determinants of innovation performance: The role of learning organization and knowledge creation," Pakistan Journal of Commerce and Social Sciences, vol. 11, no. 1, pp. 166-183, 2017.

[23] J. H. Song, "The key to organizational performance improvement: A perspective of organizational knowledge creation," Performance Improvement Quarterly, vol. 21, no. 2, pp. 87-102, 2008.

[24] Y. H. Li, J. W. Huang, and M. T. Tsai, "Entrepreneurial orientation and firm performance: The role of knowledge creation process," Industrial Marketing Management, vol. 38, pp. 440-449, 2009.

[25] N. A. Omar, H. M. Aris, and M. A. Nazri, "The effect of entrepreneurial orientation, innovation capability and knowledge creation on firm performance: A perspective on small scale entrepreneurs," Jurnal Pengurusan, vol. 48, pp. 1-23, 2016.

[26] Bank of Thailand. (November 1, 2015). Thailand's Financial Landscape. [Online].

Available: https://www.bot.or.th/English/FinancialInstitutions/FIStructure/Pages/de fault.aspx
[27] W. Teerajetgul and C. Charoenngam, "Factors inducing knowledge creation: Empirical evidence from Thai construction projects," Engineering, Construction and Architectural Management, vol. 13, no. 6, pp. 584-599, 2006.

[28] M. T. Tsai and Y. H. Li, "Knowledge creation process in new venture strategy and performance," Journal of Business Research, vol. 60, pp. 371-381, 2007

[29] K. Alfes, A. Shantz, and C. Truss, "The link between perceived HRM practices, performance and well-being: The moderating effect of trust in the employer," Human Resource Management Journal, vol. 22, no. 4, pp. 409-427, 2012.

[30] A. Kianto, P. Hurmelinna- Laukkanen, and P. Ritala, "ntellectual capital in service- and product-oriented companies," Journal of Intellectual Capital, vol. 11, no. 3, pp. 305-325, 2010.

[31] B. Dincer and C. Dincer, "Measuring brand social responsibility: A new scale," Social Responsibility Journal, vol. 8, no. 4, pp. 484-494, 2012.

[32] Z. Wang, N. Wang, and H. Liang, "Knowledge sharing, intellectual capital and firm performance," Management Decision, vol. 52, no. 2, pp. 230-258, 2014

[33] C. F. Ho, P. H. Hsieh, and W. H. Hung, "Enablers and processes for effective knowledge management," Industrial Management \& Data Systems, vol. 114, no. 5, pp. 734-754, 2014

[34] K. Lu, J. Zhu, and H. Bao, "High-performance human resource management and firm performance," Industrial Management \& Data Systems, vol. 115, no. 2, pp. 353-382, 2015.

[35] J. Sax and S. S. Torp, "Speak up! Enhancing risk performance with enterprise risk management, leadership style and employee voice," Management Decision, vol. 53, no. 7, pp. 1452-1468, 2015.

[36] M. Tavakol and R. Dennick, "Making sense of Cronbach's alpha," International Journal of Medical Education, vol. 2, pp. 53-55, 2011.

[37] M. Gloet and M. Terziovski, "Exploring the relationship between knowledge management practices and innovation performance," Journal of Manufacturing Technology Management, vol. 15, no. 5, pp. 402-409, 2004.

[38] J. W. Osborne and E. Waters, "Four assumptions of multiple regression that researchers should always test," Practical Assessment, Research \& Evaluation, vol. 8, no. 2, pp. 1-5, 2002.

[39] M. N. Williams, C. A. G. Grajales, and D. Kurkiewicz, "Assumptions of multiple regression: Correcting two misconceptions," Practical Assessment, Research \& Evaluation, vol. 18, no. 11, pp. 1-14, 2013.

[40] N. P. Kulangara, S. A. Jackson, and E. Prater, "Examining the impact of socialization and information sharing and the mediating effect of trust on innovation capability," International Journal of Operations \& Production Management, vol. 36, no. 11, pp. 1601-1624, 2016.

[41] P. Srisuphaolarn, "From altruistic to strategic CSR: How social value affected CSR development - A case study of Thailand," Social Responsibility Journal, vol. 9, no. 1, pp. 56-77, 2013.

[42] M. D. Hubers, C. L. Poortman, K. Schildkamp, J. M. Pieters, and A. Handelzalts, "Opening the black box: knowledge creation in data teams," Journal of Professional Capital and Community, vol. 1, no. 1, pp. 41-68, 2016.

[43] C. Bartolacci, C. Cristalli, D. Isidori, and F. Niccolini, "Ba virtual and inter-organizational evolution: A case study from an EU research project," Journal of Knowledge Management, vol. 20, no. 4, pp. $793-811,2016$

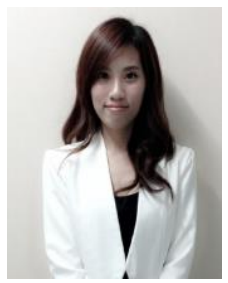

Cheewanan Arijitsatien received her bachelor of science (information and communication technology) from Mahidol University, Thailand in 2008. She is currently pursuing her master degree in management at College of Management, Mahidol University.

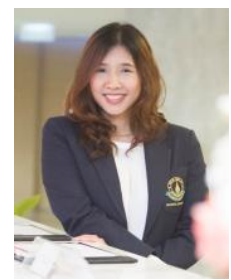

Vichita Vathanophas Ractham is currently an associate professor in the College of Management, Mahidol University, Thailand, where she teaches knowledge management, management information system, and consulting practice in the master of management, international program. Earlier, she taught in School of Computing, Department of Information System, National University of Singapore (NUS), Singapore for couple years in the same area. She received her bSc. (1992) in Business administration (concentration: Statistics) from Chulalongkorn University, Thailand and M.Sc. (1995) and Ph.D. degree (2000) in information science from University of Pittsburgh, USA. Her primary research interests include knowledge management, social interaction in teamwork, enterprise resource planning, and e-learning. 